\title{
Fungicide and Cultivar Management of Leaf Spot Diseases of Winter Wheat in Western Canada
}

H. R. Kutcher, ${ }^{\dagger}$ Crop Development Centre/Department of Plant Science, University of Saskatchewan, Saskatoon, SK S7N 5A8, Canada; T. K. Turkington, Lacombe Research and Development Centre, Agriculture and Agri-Food Canada, Lacombe, AB T4L 1W1, Canada; D. L. McLaren and R. B. Irvine, Brandon Research and Development Centre, Agriculture and Agri-Food Canada, Brandon, MB R7A 5Y3, Canada; and G. S. Brar, Crop Development Centre/Department of Plant Science, University of Saskatchewan, Saskatoon, SK S7N 5A8, Canada

\begin{abstract}
A complex of leaf-spotting diseases-tan spot, the Septoria complex, spot blotch, and powdery mildew-are frequently observed on winter wheat in western Canada; however, there are few studies indicating varietal differences in reaction to these diseases or the benefit of fungicide application. To determine the benefit of varietal improvement and multiple fungicide treatments and application timings, field experiments were conducted at six site-years in western Canada. Two cultivars varying in reaction to leaf spot diseases were used in combination with fungicide treatments. Disease severity ranged from trace to $64 \%$ of the combined flag and penultimate leaf

area diseased, differed between cultivars, and was reduced from the check by some fungicide treatments. Yield improvement by fungicide treatment varied from 3.3 to $13.2 \%$ greater than the nontreated check. At two siteyears, the split application of two half rates of fungicide resulted in the greatest yield; however, in both cases, the yield benefit did not differ from a single application at the flag leaf growth stage. Cultivar selection and fungicide use under environments conducive to disease are beneficial components of an integrated leaf spot disease management program for winter wheat in western Canada.
\end{abstract}

Winter wheat (Triticum aestivum L.) cultivation in the northern Great Plains of North America is an alternative to spring wheat production and offers advantages such as high yield potential and weed competitiveness (Beres et al. 2016). Although the area under winter wheat cultivation in western Canada has increased over the past two decades, it is still not comparable with that of spring wheat. Diseases and other pest issues limit winter wheat cultivation in western Canada. Leaf-spotting diseases of winter wheat are frequently observed and are widespread in western Canada (Fernandez et al. 2016). The more common leaf-spotting diseases include tan spot (caused by Pyrenophora tritici-repentis (Died.) Drechs.), the Septoria complex (caused by Zymoseptoria tritici (Roberge ex Desm.) Quaedvl. \& Crous and Parastagonospora nodorum (Berk.) Quaedvlieg, Verkley $\&$ Crous), and spot blotch (caused by Bipolaris sorokiniana Shoemaker) (Bailey et al. 1994; Fernandez et al. 2016). Powdery mildew (caused by Blumeria graminis (DC.) Speer f. sp. tritici Ém. Marchal) is observed occasionally in years where climatic conditions are conducive to its development. Winter wheat may escape the impact of some diseases such as Fusarium head blight (Fusarium spp.) due to its early development and maturity (Gilbert and Haber 2013). Flag leaf damage by these pathogens is of particular concern because the flag leaf contributes the most to grain development and filling, which ultimately affect yield (Willyerd et al. 2015).

The prevalence of leaf-spotting pathogens varies with soil-climatic region (rainfall and high minimum daily temperatures, in particular), wheat class, the crop production system (conventional or no-till production), and the diversity of crop rotation (Bailey 1996; Fernandez et al. 2016; Gilbert et al. 1998; Krupinsky et al. 2004; Stover et al. 1996). The impact of leaf-spotting diseases on spring wheat and the evaluation of management practices to control these diseases have been reported in a number of studies (Fernandez et al. 1998, 1999, 2016; Gilbert and Woods 2001; Krupinsky et al. 2004; Wang et al. 2002). Additionally, various studies have reported that leafspotting diseases negatively affect yield and quality of spring wheat (Eyal and Ziv 1974; King et al. 1983) and winter wheat (Gaurilčikiené and Ronis 2006; Lopez et al. 2015; Ransom and

${ }^{\dagger}$ Corresponding author: H. R. Kutcher; E-mail: randy.kutcher@usask.ca

Accepted for publication 13 March 2018.

() 2018 The American Phytopathological Society
McMullen 2008; Thompson et al. 2014). Spring wheat cultivars registered and recommended for production in the late 1980s and early 1990s were moderately susceptible to leaf spot diseases and estimated annual losses were as high as $20 \%$ at that time (Gilbert and Tekauz 1993). In contrast, Wang et al. (2002) indicated that the leaf-spotting diseases generally have a small effect on yield and seed characteristics of spring wheat in the semiarid environment of southern Saskatchewan. In the United States, yield increases of 5 to $44 \%$ in North Dakota and 5 to $37 \%$ in Oklahoma from foliar fungicides were reported under high disease pressure in hard red winter wheat (Ransom and McMullen 2008; Thompson et al. 2014).

Crop losses in wheat from foliar diseases can be managed through the use of fungicides, rotation, and tillage (Bailey et al. 2000; Duczek and Jones-Flory 1994; Ransom and McMullen 2008). Fall application of fungicides to winter wheat has been studied in western Canada but Turkington et al. (2016) reported decreased net returns. Fungicide evaluation and the use of integrated disease management practices in winter wheat also have been published from Denmark, France, and Sweden (Jørgensen et al. 2008; Loyce et al. 2008; Wiik 2008); however, few published studies on disease management for winter wheat from the Canadian prairies are available (Turkington et al. 2016). Additionally, fungicide use alone is not recommended but, rather, integrated disease management through the combined use of resistant cultivars, chemical application, and cultural practices is preferred (Willyerd et al. 2015). Information on genetic resistance to leaf spot pathogens in winter wheat cultivars of western Canada is not available in cultivar selection guides (Anonymous 2016a). Growers are advised to spray foliar fungicides on a susceptible cultivar when early infection on lower leaves is observed (Anonymous 2016b). Thus, there is no guidance for foliar fungicide application in winter wheat for leaf spot disease control in western Canada.

The objective of this study was to determine the response of two winter wheat cultivars, differentially susceptible to leaf-spotting diseases, to fungicide treatments applied at stem elongation, full emergence of the flag leaf, or as a split application at both times, over a number of site-years in western Canada. This study was designed to answer the following questions: (i) what is the effect of a fungicide application as compared with no application; (ii) what is the effect of varying the timing of a fungicide application; (iii) how do the effects of specific fungicides compare when applied only once during the growing season; and (iv) what are the effects of single applications of fungicides compared with split applications? Additionally, we asked if there is a leaf spot disease assessment measure (whole plant, 
flag leaf, penultimate leaf, or the average of both flag and penultimate) that is consistently able to differentiate treatments and predict the effect of leaf spot disease on yield and kernel quality. Information derived from this study will provide guidance for improved leaf spot control for winter wheat growers in western Canada.

\section{Materials and Methods}

Description of study sites. Field experiments were conducted at the Agriculture and Agri-Food Canada Research Stations in western Canada at Lacombe (Alberta), Melfort (Saskatchewan), and Brandon (Manitoba) in 2006; at Lacombe and Brandon in 2007; and at Melfort in 2008; for a total of six site-years. The soil at Melfort was an orthic thick black chernozem (udic boroll) silty clay loam soil. The soil at Lacombe was a black chernozem (typic haplustoll) clay loam. The soil at Brandon was an orthic black chernozem.

Experimental design and treatments. The experimental design was a split-plot with four replicates. Cultivars composed the main plots and fungicide treatments the subplots. Two winter wheat cultivars that varied in susceptibility to leaf-spotting diseases were used: CDC Osprey (susceptible) (Fowler 1997) and McClintock (moderately susceptible). Fertilizer was applied as required for maximum crop yield according to soil test recommendations. Additional $\mathrm{KCl}$ at $80 \mathrm{~kg} \mathrm{ha}^{-1}$ was broadcast in early spring. Plots were direct seeded at all locations with locally available seeding equipment, with row spacing of $23 \mathrm{~cm}$ at Melfort and Lacombe and $20.3 \mathrm{~cm}$ at Brandon. All sites were seeded in early September each year into spring wheat stubble, except at Lacombe in 2006, which was seeded into barley stubble. Seeding winter wheat into spring wheat stubble is not a recommended practice in western Canada but was followed in this study to increase the risk of leaf spot diseases. The seeding rate for both cultivars was 250 seeds $\mathrm{m}^{-2}$ to achieve a plant population of approximately 225 plants $\mathrm{m}^{-2}$.

Fungicide applications were made at either or both of two timings: A, beginning of stem elongation (growth stage [GS] 30), and B, flag leaf fully emerged (GS 39), as defined by the BBCH scale (Lancashire et al. 1991). Treatments were as follows: (i) nontreated check, (ii) pyraclostrobin (Headline, $250 \mathrm{~g} \mathrm{liter}^{-1}$ [BASF] at $0.125 \mathrm{~kg}$ active ingredient [a.i.] $\mathrm{ha}^{-1}$ ) at timing $\mathrm{B}$, (iii) propiconazole + trifloxystrobin (Stratego [Bayer Crop Science] at $125 \mathrm{~g} \mathrm{liter}^{-1}$ each a.i.) at timing B, (iv) mancozeb (Dithane Rainshield DG 75\% [Dow Agro Science] at $1.7 \mathrm{~kg}$ a.i. $\mathrm{ha}^{-1}$ ) at timing B, (v) propiconazole (Tilt $250 \mathrm{~g} \mathrm{liter}^{-1}$ [Syngenta] at $0.125 \mathrm{~kg}$ a.i. $\left.\mathrm{ha}^{-1}\right)$ at timing $\mathrm{B}$, (vi) propiconazole $(0.125 \mathrm{~kg}$ a.i. $\left.\mathrm{ha}^{-1}\right)$ at timing $\mathrm{A}$, (vii) propiconazole $\left(0.0625 \mathrm{~kg} \mathrm{a}^{\mathrm{i}}\right.$. $\left.\mathrm{ha}^{-1}\right)$ at each timing, (viii) propiconazole $\left(0.0625 \mathrm{~kg}\right.$ a.i. $\left.\mathrm{ha}^{-1}\right)$ at timing $\mathrm{A}$ and mancozeb (1.7 kg a.i. $\left.\mathrm{ha}^{-1}\right)$ at timing B, and (ix) mancozeb $\left(1.7 \mathrm{~kg}\right.$ a.i. ha $\left.{ }^{-1}\right)$ at timing $\mathrm{A}$ and propiconazole $\left(0.0625 \mathrm{~kg}\right.$ a.i. ha $\left.{ }^{-1}\right)$ at timing $\mathrm{B}$ (Table 1). Full rate applications are those registered for use in Canada. All products were applied in water at 100 liters $\mathrm{ha}^{-1}$, except propiconazole, which was applied in water at 200 liters $\mathrm{ha}^{-1}$.

Experimental measurements. Disease assessment was conducted at the soft-dough growth stage (GS 85) on 25 whole plants using the McFadden Scale (McFadden 1991). On the same 25, plants disease assessment was made of the flag and penultimate leaves using the 0-to-11 Horsfall-Barratt scale, which was converted to percentage of foliage diseased (Horsfall and Barratt 1945).

Data collected at harvest included yield (kilograms per hectare), thousand-kernel weight (TKW; grams), test weight (TW; kilograms per hectoliter), percent plump kernels (kernels that did not pass through a $2.38-\mathrm{mm}$ sieve), percent thin kernels (kernels that passed through a $1.98-\mathrm{mm}$ sieve), and percent protein content in seed (calculated by multiplying the total $\mathrm{N}$ content in seed by 5.7) (Williams et al. 1998). The weather data, which included mean air temperature $\left({ }^{\circ} \mathrm{C}\right)$, total precipitation (millimeters), and their long-term average for the growing season (May to September) for all site-years, was accessed from onsite Environment Canada weather stations.

Data analyses. To determine the effects of cultivar and fungicide treatment on disease severity and seed yield and quality, data were analyzed using Procedure MIXED (Littell et al. 1996) in Statistical Analysis Software (SAS Inc., Cary, NC). Cultivar and fungicide treatment were considered fixed factors and replicate, site, and year were considered random factors. Disease assessment of the flag and penultimate leaves, as well as an average of both leaves, were analyzed using a negative binomial error distribution. The standard Gaussian error distribution was used for all other response variables. Ordinal data of the McFadden scale were analyzed using rank-based nonparametric tests: analysis of variance-type statistics (ATS) and Wald-type statistics (WTS) (Shah and Madden 2004). Fixed treatment effects were declared significant at $P<0.05$. Orthogonal contrasts were used to assess differences among fungicide treatments and application timings.

\section{Results}

Weather conditions during the growing season for all siteyears. The temperatures at all three sites were similar to their longterm (1981 to 2010) averages (Table 2). Temperatures were slightly higher for Brandon as compared with Lacombe and Melfort, particularly in July and August. The precipitation for Lacombe 2006 was similar to the long-term normal, except in June, when it was lower. For Lacombe 2007, precipitation was two to three times higher in May and June as compared with long-term normal, and lower for the month of July. The precipitation received at Brandon was more variable than at other sites. In 2006, precipitation at Brandon was lower than normal for the months of May and July and higher than normal for August and September. In 2007, precipitation was higher than normal for May and lower for July, August, and September. Similarly, for Melfort 2006, precipitation was higher than normal for the months of May, June, and September and lower for other months. In 2007 at Melfort, however, precipitation was higher than normal in the month of July and lower for other months as compared with the long-term normal. In 2008 at Melfort, precipitation was lower than the long-term normal in all months, except June, when it was substantially greater than the long-term normal.

Fixed factors. There were no significant $(P<0.05)$ interactions among the fixed factors (cultivar and fungicide treatment) for any of the response variables. Only significant main effects are described hereafter. Among the response variables, percent thin kernels and

Table 1. List of fungicide treatments, fungicide active ingredients (a.i.), trade names, and application rates and timings used in the study

\begin{tabular}{lllcl}
\hline Treatment number & \multicolumn{1}{c}{ Chemical name } & Trade name & ${\left.\text { Rate (a.i. } \mathbf{k g} \mathbf{h a}^{-\mathbf{1}}\right)^{\mathbf{a}}}^{\text {Application timing }}$ \\
\hline 1 & Nontreated check & $\ldots$ & $\ldots$ & $\ldots$ \\
2 & Pyraclostrobin & Headline & 0.125 & Flag leaf fully emerged (GS 39) \\
3 & Propiconazole + trifloxystrobin & Stratego & 125 & GS 39 \\
4 & Mancozeb & Dithane & 1.7 & GS 39 \\
5 & Propiconazole & Tilt & 0.125 & GS 39 \\
6 & Propiconazole & Tilt & 0.125 & Beginning of stem elongation (GS 30) \\
7 & Propiconazole & Tilt & 0.0625 & GS 30 + GS 39 \\
8 & Propiconazole and mancozeb & Tilt, Dithane & $0.0625,1.7$ & GS 30, GS 39 \\
9 & Mancozeb and propiconazole & Dithane, Tilt & $1.7,0.0625$ & GS 30, GS 39 \\
\hline
\end{tabular}

a All active ingredients in $\mathrm{kg} \mathrm{ha}^{-1}$ except Stratego, which was in $\mathrm{g}$ liter. ${ }^{-1}$

${ }^{\mathrm{b}} \mathrm{GS}=\mathrm{BBCH}$ growth stage (Lancashire et al. 1991). 
percent protein content were not affected by any of the fixed factors. Results of nonparametric analyses of the McFadden scale data were similar for ATS and WTS, likely because of the large sample size.

Incidence of leaf-spotting pathogens. The diseases observed over the course of this study included tan spot, the Septoria complex, and powdery mildew. In general, for almost every site-year, tan spot and the Septoria complex were the two main diseases. Powdery mildew only occurred at Melfort in 2008. In the nontreated control plots of both cultivars and in all site-years, the range of leaf spot severity varied widely from 0 to $95.5 \%$, depending on the leaves (flag, penultimate, or average of both) assessed (Table 3). Similarly, the range of leaf spot disease severity measured over the whole plant varied widely, from 1.6 to 10.9 .

The cultivar McClintock consistently had lower leaf spot severity ratings for the flag and penultimate leaves, the average of the two, and the whole plant, compared with Osprey (Tables 3 and 4). Over the course of the study period, ratings for leaf spot disease severity in the nontreated check plots varied with site-year but generally were relatively low. For five site-years (Brandon, Melfort, and Lacombe in 2006 and Brandon and Lacombe in 2007), mean leaf spot severity for the flag and penultimate leaves and their average varied from a low of $1.7 \%$ for the flag leaf at Lacombe 2007 to a high of $26.8 \%$ for the penultimate leaf at Melfort 2006 (Table 3). Mean leaf spot severity ratings for the whole plant for these site-years varied from a low of 3.5 at Lacombe 2006 to a high of 8.7 at Brandon 2006. Leaf spot disease severity ratings of the nontreated check plots were substantially higher at Melfort 2008. Mean leaf spot disease severity for the flag and penultimate leaves and their average varied from a low of 44.4 for the flag leaf to a high of 82.7 for the penultimate leaf. The mean whole-plant leaf spot severity rating for this site-year in the nontreated check plots was 10.1 .

Table 2. Mean air temperature (Temp) and total precipitation (Precip) (May to September) at six site-years under study ${ }^{\mathrm{a}}$

\begin{tabular}{|c|c|c|c|c|c|c|c|c|c|}
\hline Month & $\begin{array}{c}\text { Lacombe } \\
2006\end{array}$ & $\begin{array}{c}\text { Melfort } \\
2006\end{array}$ & $\begin{array}{c}\text { Brandon } \\
2006\end{array}$ & $\begin{array}{l}\text { Lacombe } \\
2007\end{array}$ & $\begin{array}{c}\text { Brandon } \\
2007\end{array}$ & $\begin{array}{c}\text { Melfort } \\
2008^{b}\end{array}$ & $\begin{array}{c}\text { Lacombe } \\
\text { long-term }^{c}\end{array}$ & $\begin{array}{c}\text { Melfort } \\
\text { long-term }\end{array}$ & $\begin{array}{l}\text { Brandon } \\
\text { long-term }\end{array}$ \\
\hline \multicolumn{10}{|l|}{ Temp $\left({ }^{\circ} \mathrm{C}\right)$} \\
\hline May & 11.3 & 11.1 & 11.6 & 9.8 & 10.8 & 9.1 & 9.7 & 10.7 & 11.4 \\
\hline June & 15.3 & 16.7 & 17.2 & 14.9 & 16.3 & 15.0 & 13.7 & 15.9 & 16.6 \\
\hline July & 17.6 & 18.3 & 19.9 & 19.1 & 20.6 & 16.7 & 15.9 & 17.5 & 19.2 \\
\hline August & 14.7 & 17.1 & 18.9 & 13.2 & 16.5 & 17.3 & 14.9 & 16.8 & 18.2 \\
\hline September & 11.1 & 11.4 & 12.1 & 9.4 & 11.9 & 11.0 & 9.9 & 10.8 & 12.2 \\
\hline \multicolumn{10}{|l|}{ Precip (mm) } \\
\hline May & 55.1 & 63.0 & 41.0 & 117.9 & 84.4 & 6.1 & 47.2 & 39.8 & 52.1 \\
\hline June & 66.4 & 73.6 & 81.6 & 174.0 & 80.8 & 32.0 & 94.0 & 54.3 & 79.6 \\
\hline July & 89.0 & 38.6 & 7.8 & 48.8 & 51.4 & 117.8 & 94.4 & 76.7 & 68.2 \\
\hline August & 74.4 & 45.4 & 76.4 & 69.2 & 49.2 & 22.1 & 71.2 & 52.4 & 65.5 \\
\hline September & 50.6 & 118.8 & 74.6 & 46.0 & 19.6 & 11.4 & 47.4 & 34.3 & 41.6 \\
\hline
\end{tabular}

a The long-term average temperature and total precipitation was obtained for the period 1981 to 2010 from Environment Canada (long-term climate normal).

b Weather data for Melfort and Brandon were obtained from the onsite Environment Canada weather stations (http://climate.weather.gc.ca/climate_normals/).

${ }^{c}$ Long-term averages for Lacombe were assessed from Red Deer, Alberta which is the closest to Lacombe.

Table 3. Severity of leaf-spotting diseases of winter wheat during the study period in the nontreated check plots, based on the mean and range for leaf-spotting disease severity for the flag and penultimate leaves, the average of the flag and penultimate leaves (percent based on Horsfall-Barratt scale), and for the whole plant (based on the McFadden scale), for cultivar and site-year

\begin{tabular}{|c|c|c|c|c|}
\hline Cultivar or site-year & Flag $(\%)$ & Penultimate (\%) & Average of both leaves $(\%)^{\mathbf{a}}$ & McFadden (0-11) ${ }^{\mathrm{b}}$ \\
\hline $\begin{array}{l}\text { Average of all cultivars and site-years } \\
\text { combined }\end{array}$ & $13.1(0-75.6)$ & $29.0(0.2-95.5)$ & $21.0(0.1-85.3)$ & $7.0(1.6-10.9)$ \\
\hline \multicolumn{5}{|l|}{ Cultivar } \\
\hline McClintock & $10.7(0-50.7)$ & $21.8(0.2-94.9)$ & $16.2(0.1-85.3)$ & $6.2(1.6-10.9)$ \\
\hline Osprey & $15.6(1.5-50.5)$ & $36.6(9.2-95.5)$ & $26.1(7.0-72)$ & $7.9(3.2-10.9)$ \\
\hline \multicolumn{5}{|l|}{ Site-year } \\
\hline Brandon 2006 & $5.2(2.4-9.0)$ & $8.6(5.2-11.0)$ & $6.9(3.8-10.0)$ & $8.7(6.7-10.4)$ \\
\hline Melfort 2006 & $9.3(2.1-28.1)$ & $26.8(9.1-61.3)$ & $18.0(5.6-44.7)$ & $7.3(6.0-9.0)$ \\
\hline Lacombe $2006^{c}$ & - & - & - & $3.5(2.2-4.8)$ \\
\hline Brandon 2007 & $4.3(2.3-6.4)$ & $15.5(2.9-25.0)$ & $9.9(2.6-15.2)$ & $7.6(5.5-8.5)$ \\
\hline Lacombe 2007 & $1.7(0-5.8)$ & $10.0(0.2-21.0)$ & $5.8(0.1-13.4)$ & $4.9(1.6-7.2)$ \\
\hline Melfort 2008 & $44.4(12.1-75.6)$ & $82.7(48.6-95.5)$ & $63.5(30.3-85.3)$ & $10.1(7.9-10.9)$ \\
\hline
\end{tabular}

${ }^{a}$ Refer to Horsfall and Barratt (1945).

${ }^{b}$ Refer to McFadden (1991).

c Symbol: - indicates no data due to above normal temperatures that caused flag and penultimate leaves to senesce prematurely.

Table 4. Effect of cultivar on leaf spot disease severity, yield, thousand kernel weight (TKW), test weight (TW), plump and thin kernels, and protein content of winter wheat for fungicide treatment and site-year combined

\begin{tabular}{|c|c|c|c|c|c|c|c|c|c|c|}
\hline Cultivar & $\begin{array}{c}\text { Flag leaf } \\
(\%)^{\mathrm{a}}\end{array}$ & $\begin{array}{l}\text { Penultimate } \\
\text { leaf }(\%)^{\mathrm{a}}\end{array}$ & $\begin{array}{l}\text { Average both } \\
\text { leaves }(\%)^{\mathrm{a}}\end{array}$ & $\begin{array}{c}\text { McFadden } \\
(0-11)^{\mathbf{b}}\end{array}$ & $\underset{\left(\mathrm{kg} \mathrm{ha}^{-1}\right)}{\text { Yield }}$ & $\begin{array}{c}\text { TKW } \\
(\mathrm{g})\end{array}$ & $\begin{array}{c}\mathrm{TW} \\
\left(\mathrm{kg} \mathrm{hl}^{-1}\right)\end{array}$ & $\begin{array}{c}\text { Plump } \\
\text { kernels (\%) }\end{array}$ & $\begin{array}{c}\text { Thin kernels } \\
(\%)\end{array}$ & $\begin{array}{l}\text { Protein } \\
(\%)\end{array}$ \\
\hline McClintock & 10.7 & 17.3 & 14.0 & 5.3 & 4481 & 32.1 & 80.3 & 69.8 & 3.8 & 11.4 \\
\hline Osprey & 12.5 & 25.2 & 18.8 & 6.3 & 4367 & 30.1 & 77.8 & 68.7 & 4.7 & 11.2 \\
\hline$P$ value ${ }^{\mathrm{c}}$ & 0.158 & 0.049 & 0.072 & $<0.001$ & 0.452 & 0.008 & $<0.001$ & 0.489 & 0.175 & 0.417 \\
\hline
\end{tabular}

${ }^{a}$ Percent severity determined according to Horsfall and Barratt (1945).

b Ordinal scale of McFadden (1991). The significance value was calculated using nonparametric analysis of variance-type statistics (Shah and Madden 2004).

${ }^{c} P$ value for main effect of cultivar. Data in bold indicate significant differences between cultivars. 
Cultivar effect. Leaf spot disease severity of the penultimate leaf and for the whole plant differed significantly for the main effect of cultivar. Disease severity ratings for the penultimate leaf and for the whole plant for Osprey were greater than for McClintock, as indicated from the estimated rank (Table 4). Leaf spot disease severity ratings for the flag leaf and for the average of the flag and penultimate leaves did not differ significantly. Additionally, TKW and TW varied between the cultivars and were correlated with disease severity. Both TKW and TW were greater for McClintock than for Osprey (Table 4).

Fungicide treatments effect. All response variables except percent thin kernels and percent protein varied for the fixed effect of fungicide treatment (all $P<0.001$, except for leaf spot disease severity of the flag leaf, where $P=0.006$ ) (Table 5). The linear contrast of the untreated check plots versus all treated plots combined indicated a difference between the two groups for all disease severity ratings, for yield, and for percent plump kernels (Table 5). For the most part, disease severity of the untreated control was higher than for the treated plots, and disease severity was correlated with lower yield, TKW, TW, and percent plump kernels (Table 5). The linear contrast of fungicide application at the flag stage versus an application of propiconazole at stem elongation was not significant for any response variable, suggesting that the timing of fungicide application did not affect leaf spot disease severity, yield, or any kernel quality measures (Table 5).

For the linear contrast of single applications of any fungicide at the flag stage versus split application of any fungicide at both stem elongation and flag leaf stages, only leaf spot disease severity of the flag leaf and yield differed between the two groups (Table 5). On average, disease severity of the flag leaf for the split fungicide applications was lower than for single applications. This rating was correlated with a somewhat higher yield.

For the linear contrast among fungicides pyraclostrobin, propiconazole + trifloxystrobin, mancozeb, and propiconazole, all measures of disease severity differed significantly, as did yield and kernel quality variables (Table 5). When fungicides were applied at the flag leaf stage, disease severity was highest for mancozeb, followed by propiconazole, then propiconazole + trifloxystrobin, and lowest for pyraclostrobin (Table 5). Disease severity was correlated with yield for all fungicides. Yield and kernel quality tended to be correlated with disease severity for fungicides but the relationship was somewhat inconsistent. Yield, TKW, TW, and percent plump kernels were highest, and percent thin kernels was lowest, for pyraclostrobin and propiconazole + trifloxystrobin. Percent protein was the highest for propiconazole + trifloxystrobin and marginally lower for pyraclostrobin as compared with propiconazole. Propiconazole + trifloxystrobin was superior to pyraclostrobin in terms of yield and kernel quality. Of the fungicides examined, mancozeb resulted in the lowest yield and kernel quality.

A linear contrast among the split fungicide treatments was not significant for any response variable except TKW. The split application of propiconazole applied at half the recommended rate at stem elongation and mancozeb applied at flag stage resulted in slightly lower TKW than the other two split-application fungicide treatments (Table 5).

It was considered that fungicide treatment effects might vary with site-year, depending on the overall incidence of disease. Melfort in 2008 had considerably greater levels of leaf spot disease severity; therefore, the data for the contrasted fungicide treatment groups for this site-year were examined relative to the results for the linear contrasts based on all site-years. However, no outstanding variance was observed (data not shown).

\section{Discussion}

The occurrence of leaf-spotting diseases of winter wheat over the course of this study was similar to observations reported in other

Table 5. Effect of fungicide treatment on leaf spot disease severity, yield, thousand kernel weight (TKW), test weight (TW), plump and thin kernels, and protein content of winter wheat for cultivar and site-year combined ${ }^{\mathrm{a}}$

\begin{tabular}{|c|c|c|c|c|c|c|c|c|c|c|}
\hline Fungicide treatment ${ }^{\mathbf{b}}$ & $\begin{array}{c}\text { Flag leaf } \\
(\%)^{c}\end{array}$ & $\begin{array}{l}\text { Penultimate } \\
\text { leaf }(\%)^{\mathbf{b}}\end{array}$ & $\begin{array}{l}\text { Average both } \\
\text { leaves }(\%)^{\mathbf{b}}\end{array}$ & $\begin{array}{l}\text { McFadden } \\
(\mathbf{0}-11)^{\mathrm{d}}\end{array}$ & $\begin{array}{c}\text { Yield } \\
\left(\mathrm{kg} \mathrm{ha}^{-1}\right)\end{array}$ & $\underset{(\mathrm{g})}{\mathbf{T K W}}$ & $\begin{array}{c}\text { TW } \\
\left(\mathrm{kg} \mathrm{hl}^{-1}\right)\end{array}$ & $\begin{array}{l}\text { Plump } \\
\text { kernels }(\%)\end{array}$ & $\begin{array}{c}\text { Thin } \\
\text { kernels } \\
(\%)\end{array}$ & $\begin{array}{l}\text { Protein } \\
(\%)\end{array}$ \\
\hline \multicolumn{11}{|l|}{ Mean } \\
\hline 1. Nontreated & 5.7 & 17.3 & 11.8 & 7.0 & 4,101 & 30.6 & 78.4 & 65.8 & 5.8 & 11.2 \\
\hline 2. Pyraclostrobin at GS39 & 2.7 & 7.2 & 5.1 & 5.2 & 4,445 & 31.5 & 79.3 & 72.4 & 4.4 & 11.3 \\
\hline $\begin{array}{l}\text { 3. Propiconazole }+ \\
\text { trifloxystrobin at GS39 }\end{array}$ & 3.1 & 7.7 & 5.5 & 5.4 & 4,565 & 31.9 & 79.6 & 73.3 & 3.9 & 11.6 \\
\hline 4. Mancozeb at GS39 & 6.1 & 18.2 & 12.5 & 7.1 & 4,236 & 30.2 & 78.5 & 66.6 & 5.8 & 11.0 \\
\hline 5. Propiconazole at GS39 & 4.2 & 9.0 & 6.8 & 5.7 & 4,431 & 31.2 & 79.1 & 68.5 & 5.9 & 11.4 \\
\hline 6. Propiconazole at GS30 & 3.7 & 9.1 & 6.6 & 5.9 & 4,495 & 31.1 & 79.1 & 68.8 & 5.2 & 11.2 \\
\hline 7. Propiconazole split & 2.9 & 5.7 & 4.4 & 5.0 & 4,643 & 31.7 & 79.4 & 71.8 & 4.5 & 11.2 \\
\hline $\begin{array}{l}\text { 8. Propiconazole }+ \\
\text { mancozeb split }\end{array}$ & 3.8 & 9.7 & 6.9 & 5.6 & 4,456 & 30.6 & 78.9 & 69.0 & 5.0 & 11.2 \\
\hline $\begin{array}{l}\text { 9. Mancozeb }+ \\
\text { propiconazole split }\end{array}$ & 3.5 & 7.9 & 5.9 & 5.4 & 4,443 & 31.2 & 79.1 & 70.3 & 4.7 & 11.4 \\
\hline \multicolumn{11}{|l|}{$P$ values } \\
\hline Main effect of fungicide & 0.006 & $<0.001$ & $<0.001$ & $<0.001$ & $<0.001$ & $<0.001$ & $<0.001$ & $<0.001$ & 0.057 & 0.236 \\
\hline \multicolumn{11}{|l|}{ Contrast $^{\mathrm{e}}$} \\
\hline Untreated vs. all treated & $<0.001$ & 0.009 & 0.001 & $<0.001$ & $<0.001$ & 0.042 & $<0.001$ & 0.001 & 0.085 & 0.466 \\
\hline $2+3+4+5$ vs. 6 & 0.839 & 0.870 & 0.759 & 0.935 & 0.357 & 0.770 & 0.581 & 0.294 & 0.742 & 0.506 \\
\hline $2+3+4+5$ vs. $7+8+9$ & 0.011 & 0.327 & 0.112 & $n s^{\mathrm{f}}$ & 0.045 & 0.842 & 0.934 & 0.869 & 0.509 & 0.264 \\
\hline 2 vs. 3 vs. 4 vs. 5 & $<0.001$ & 0.001 & $<0.001$ & $<0.001$ & $<0.001$ & $<0.001$ & $<0.001$ & $<0.001$ & 0.015 & 0.050 \\
\hline 7 vs. 8 vs. 9 & 0.525 & 0.103 & 0.180 & $\mathrm{~ns}$ & 0.106 & 0.008 & 0.161 & 0.245 & 0.760 & 0.430 \\
\hline
\end{tabular}

${ }^{\text {a }}$ Data in bold indicate significant $P$ values for the effect of fungicides and contrasts among treatments.

${ }^{\mathrm{b}}$ Fungicide treatments: nontreated check; pyraclostrobin at growth stage (GS)39= pyraclostrobin applied at flag stage; propiconazole + trifloxystrobin at GS39= propiconazole + trifloxystrobin applied at flag leaf stage; mancozeb at GS39 = mancozeb applied at flag stage; propiconazole at GS39= propiconazole applied at flag leaf stage; propiconazole at GS30 = propiconazole applied at stem elongation stage; propiconazole split = propiconazole applied at half the label rate at GS30 and again at GS 39; propiconazole + mancozeb split = propiconazole applied at half the label rate at stem elongation and mancozeb applied at the label rate at flag leaf stage; and mancozeb + propiconazole split = mancozeb applied at stem elongation and propiconazole applied at half the label rate at flag leaf stage.

${ }^{\mathrm{c}}$ Linear contrasts of specific treatment groups.

${ }^{\mathrm{d}}$ Refer to Horsfall and Barratt (1945).

e Refer to McFadden (1991). The significance values for the contrasts were calculated using nonparametric analysis of variance-type statistics (Shah and Madden 2004).

${ }^{\mathrm{f}}$ Values were not generated because of very low variation. 
studies in western Canada. Both tan spot and the Septoria complex were the most common leaf spot diseases observed, similar to the observations in spring wheat of Bailey et al. (1994), Fernandez et al. (2016), and Gilbert et al. (1998). Powdery mildew was observed only at Melfort in 2008, when climatic conditions were conducive for its development (Table 2). The relatively low to moderate leaf spot disease severity for all site-years except Melfort 2008, where disease severity was moderate to high, was likely associated with dry spring (May and June) conditions followed by above-average rainfall during July in that site-year.

Little information is available for leaf spot disease susceptibility or resistance in winter wheat cultivars suitable for western Canada. For example, the Saskatchewan Seed Guide 2016 (Anonymous 2016a) does not list the relative resistance of winter wheat cultivars to leaf-spotting diseases, whereas such information is available for spring wheat classes. The current study determined the relative resistance by the cultivars McClintock and Osprey to leaf-spotting diseases, with Osprey the more susceptible. Both TKW and TW were correlated with disease severity. The greater susceptibility of Osprey than McClintock to leaf-spotting diseases was associated with lower TKW and TW (Table 4).

Similar to other studies, we found that, in general, fungicide application reduced leaf spot disease severity and improved yield and quality. Propiconazole has been reported to reduce foliar disease severity in moderately leaf spot resistant cultivars of spring wheat in 2 of 4 years (Bailey et al. 2000) and in 3 of 4 years (Kutcher et al. 2011), indicating a somewhat inconsistent yield response. Although fungicide applications may reduce disease severity, they may not be economical at disease levels at or below $10 \%$ damage to the flag or penultimate leaf by the soft dough stage because seed yield or quality may not increase (Stover et al. 1996). The decision to use fungicides should be based on the incidence and severity of disease, when possible (Bailey et al. 2000). In addition, consideration should be given to the crop growth stage; current and future weather conditions during the season; previous history of leaf spot diseases; tillage system, which may affect the amount of previous crop residue and, therefore, disease inoculum; the frequency of cereal production in the rotation; and the cost of fungicide and application and the expected crop revenue (Kutcher et al. 2011).

The difference in the benefits achieved among fungicides in this study was relatively small but the risk of yield loss is considerably lower in resistant cultivars (Jørgensen et al. 2008). In a recent study from the Great Plains of the United States, Wegulo et al. (2011) reported that foliar fungicide application is profitable under moderate to high disease severity; however, a net economic loss can result if applied in years with low disease severity. Furthermore, these authors state that, although fungicide application is generally recommended to minimize disease-induced yield losses, the cost of the fungicide must be balanced with increased yields. In the current study, the interaction of fungicide and cultivar was not significant for any of the response variables. Although McClintock was somewhat less affected by leaf-spotting diseases than Osprey, it was still in the low to moderate range. As a consequence, McClintock responded to fungicide application as well as Osprey. Cultivars with greater differences in genetic resistance to leaf-spotting diseases may exhibit differential effects due to fungicide treatment.

In contrast to the results of the current study, some researchers report that the timing of fungicide application is important. In Saskatchewan, the optimal time of applications of propiconazole on spring wheat was reported to be between the extension of the flag leaf growth stage and the medium milk growth stage, which increased yield by up to $10 \%$, although the effect varied with cultivar (Duczek and Jones-Flory 1994). Wang et al. (2002) found that, in general, application of tebuconazole (Folicur 3.6F) and chlorothalonil (Bravo 500) reduced leaf-spotting disease severity on both the flag and penultimate leaves, and that early applications, at or before flag leaf emergence, were more effective than later applications. A recent study from Illinois, Indiana, Ohio, and Wisconsin in the United States on soft red winter wheat concluded that the application of foliar fungicides before flag leaf emergence (BBCH GS 37) was not effective in reducing leaf spot disease severity or increasing yield, and that the application of pyraclostrobin or pyraclostrobin + tebuconazole at half the recommended rate may be as effective as a full rate at GS 39 (Willyerd et al. 2015).

In the current study, split fungicide applications at both stem elongation (GS 30) and flag leaf (GS 39) tended to decrease leaf spot disease severity on the flag leaf and increase yield relative to single applications of fungicide applied at GS 39. Among the three split application treatments, propiconazole applied at half the recommended rate at GS 30 and mancozeb applied at GS 39 resulted in a slightly lower TKW than that of the other two split fungicide treatments. Although not significant, all ratings for leaf spot disease severity for this particular split application were somewhat higher than those of the other two split applications, which may explain the difference in TKW. The value of split fungicide applications depends on the balance between disease risk, input costs, and final yield and crop quality (Jørgensen et al. 2008; Stover et al. 1996; Willyerd et al. 2015).

Strobilurin-based fungicides were reported to be more effective at reducing Stagonospora leaf blotch and tan spot disease severity in winter wheat than was propiconazole (Gaurilčikiene and Ronis 2006). Results from the current study concur, in part, with this finding, with the exception that the use of pyraclostrobin alone did not improve yield or quality components, whereas a mixture of a strobilurin-based fungicide and a triazole (propiconazole + trifloxystrobin) did.

The current study used four measurements of leaf spot severity. It was thought that the disease severity rating of the flag leaf in particular might be the most consistent for differentiating fixed effects and treatment groups on the basis of measuring leaf spot disease severity, and at predicting the effects of leaf-spotting disease on measures of yield or kernel quality. In general, the flag leaf contributes substantially more than other leaves to yield (Gooding et al. 2000; Walpole and Morgan 1974), and the application of fungicide before or at emergence of the flag leaf to control leaf-spotting diseases keeps upper leaves healthy, delays early senescence of the flag leaf, and, thus, contributes to higher yields (Cook et al. 1999; Gooding et al. 2000; Wiik 2008). The increase in yield and reduced leaf spot diseases on the flag leaf with early application (flag leaf emergence) could be attributed to that fact that Stagonospora leaf blotch and the Septoria leaf spot pathogens may become established in fall and overwinter as asymptomatic lesions and resume fungal growth in early spring (Bergstrom 2010).

For the contrast of the untreated plots versus all treated plots, and for the contrast of single applications of specific fungicides, all measures of disease severity differed among the groups contrasted, and were correlated with each other for any one fungicide. In turn, these disease ratings were, in very large part, correlated with yield and kernel quality. There were two exceptions to this. One was for the main effect of cultivar, where only the disease severity ratings for the penultimate leaf and for the whole plant were significant. In this case, the two disease severity ratings were correlated with one another, and with TKW and TW for either cultivar. It is suspected that the differential susceptibility of the two cultivars, in combination with disease development, was associated with the difference between the penultimate leaf rating and the whole plant rating. The second exception was for the contrast between single fungicide applications and split fungicide applications, where only the disease severity rating for the flag leaf and yield differed between the two groups. In this case, yield was correlated with disease severity as measured by the rating of the flag leaf. Again, it is suspected that the timing of the split fungicide applications, in combination with disease development, was associated with this result.

Consequently, in the current study, there was no clear indication that any one rating for disease severity could be used consistently to differentiate fixed effects or treatment groups on the basis of leaf spot disease severity, or to predict the effect of leaf spot disease on yield or kernel quality. Wang et al. (2002) used flag leaf rating in 1 year of their study, and both the flag and penultimate leaves for 2 years. In large part, these two ratings were correlated in their study, although there were some inconsistencies. These authors also suggest 
that any one disease severity rating could not be used to differentiate fixed effects or treatment groups on the basis of measuring leaf spot disease severity, or to predict the effect of leaf spot disease on any of the yield components or kernel quality.

Tan spot and the Septoria complex were the main leaf-spotting diseases observed during the study period, while powdery mildew was observed at one site-year. Leaf spot disease severity was somewhat higher for Osprey than for McClintock. Fungicide application reduced leaf spot disease severity and increased yield, TKW, TW, and percent plump kernels relative to the nontreated control. An application of pyraclostrobin applied at the flag stage resulted in the lowest leaf spot disease severity but the application of propiconazole + trifloxystrobin at the flag stage resulted in the greatest yield and kernel quality. Flag leaf disease severity tended to be lower and yield higher with split applications of fungicide than with single applications. Fungicide application timing did not affect leaf spot disease severity, yield, or kernel quality. Except for Melfort in 2008, precipitation tended to be lower than the long-term averages, especially in July. Thus, conditions during grain filling were less conducive to leafspotting diseases than in years with greater precipitation, thereby limiting potential differences in fungicide application timing. There was no clear indication that any one assessment method for disease severity could be used consistently to differentiate fixed effects or treatment groups on the basis of measuring leaf spot disease severity, or to predict the effect of leaf spot disease on any of the yield components or kernel quality. This study demonstrated that cultivar resistance and fungicide application are important management strategies to mitigate leaf-spotting diseases and improve yield and kernel quality of winter wheat in western Canada. Split applications of fungicide may improve yield and kernel quality, and the use of strobilurinbased fungicides, alone or mixed with a triazole, or possibly fungicides from other groups, may result in superior disease control, yield, and kernel quality.

\section{Acknowledgments}

We thank C. Kirkham, D. Cross, B. Mollison, T. Henderson, R. Pacholok, N. Rauhala, D. Orr, D. Clark, and J. Busaan for their excellent technical assistance; and R. G. St-Pierre for assistance with statistical analysis and manuscript preparation.

\section{Literature Cited}

Anonymous. 2016a. Varieties of Grain Crops 2016. In: 2016 Guide. Saskatchewan Seed Growers Association, Regina, Saskatchewan.

Anonymous. 2016b. Winter Wheat Production Manual. Online publication. University of Saskatchewan. https://www.usask.ca/agriculture/plantsci/winter_ cereals/winter-wheat-production-manual/index.php

Bailey, K. L. 1996. Diseases under conservation tillage. Can. J. Plant Sci. 76:635-639. Bailey, K. L., Duczek, L. J., Jones-Flory, L., Kutcher, H. R., Fernandez, M. R., Hughes, G. R., Kaminski, D., Kirkam, C. L., Mortensen, K., Boyetchko, S., Burnett, P., and Orr, D. 1994. Saskatchewan/Central Alberta wheat disease survey, 1993. Can. Plant Dis. Surv. 74:79-82.

Bailey, K. L., Johnston, A. M., Kutcher, H. R., Gossen, B. D., and Morrall, R. A. A. 2000. Managing crop losses from foliar diseases with fungicides, rotation, and tillage in the Saskatchewan Parkland. Can. J. Plant Sci. 80:169-175.

Beres, B. L., Turkington, T. K., Kutcher, H. R., Irvine, B. I., Johnson, E. N., O'Donovan, J. T., Harker, K. N., Holzapfel, C. B., Mohr, R., Peng, G., and Spaner, D. M. 2016. Winter wheat cropping system response to seed treatments, seed size, and sowing density. Agron. J. 108:1101-1111.

Bergstrom, G. C. 2010. Stagonospora nodorum blotch and Stagonospora avenae blotch. Pages 75-77 in: Compendium of Wheat Diseases and Pests. W. W. Bockus, R. L. Bowden, R. M. Hunger, W. L. Morrill, T. D. Murray, and R. W. Smiley, eds. American Phytopathological Society, St. Paul, MN.

Cook, R. J., Hims, M. J., and Vaughan, T. B. 1999. Effects of fungicide spray timing on winter wheat disease control. Plant Pathol. 48:33-50.

Duczek, L. J., and Jones-Flory, L. L. 1994. Effect of timing of propiconazole application on foliar disease and yield of irrigated spring wheat in Saskatchewan from 1990 to 1992. Can. J. Plant Sci. 74:205-207.

Eyal, Z., and Ziv, V. 1974. The relationship between epidemics of Septoria leaf blotch and yield losses in spring wheat. Phytopathology 64:1385-1389.

Fernandez, M. R., McConkey, B. G., and Zentner, R. P. 1999. Effects of tillage method and fallow frequency on leaf spotting diseases of spring wheat in the semiarid Canadian prairies. Soil Tillage Res. 50:259-269.

Fernandez, M. R., Wang, H., Cutforth, H., and Lemke, R. 2016. Climatic and agronomic effects on leaf spots of spring wheat in the western Canadian Prairies. Can. J. Plant Sci. 96:895-907.
Fernandez, M. R., Zentner, R. P., McConkey, B. G., and Campbell, C. A. 1998. Effects of crop rotations and fertilizer management on leaf spotting diseases of spring wheat in southwestern Saskatchewan. Can. J. Plant Sci. 78: 489-496.

Fowler, D. B. 1997. CDC Osprey winter wheat. Can. J. Plant Sci. 77:665-667.

Gaurilčikienè, I., and Ronis, A. 2006. The effect of strobilurin fungicides on the development of foliar diseases of winter wheat. Agron. Res. (Tartu) 4:177-180.

Gilbert, J., and Haber, S. 2013. Overview of some recent research developments in Fusarium head blight of wheat. Can. J. Plant Pathol. 35:149-174.

Gilbert, J., and Tekauz, A. 1993. Reaction of Canadian spring wheats to Septoria nodorum and the relationship between disease severity and yield components Plant Dis. 77:398-402.

Gilbert, J., and Woods, S. M. 2001. Leaf spot diseases of spring wheat in southern Manitoba farm fields under conventional and conservation tillage. Can. J. Plant Sci. 81:551-559.

Gilbert, J., Woods, S. M., and Tekauz, A. 1998. Relationship between environmental variables and the prevalence and isolation frequency of leafspotting pathogens in spring wheat. Can. J. Plant Pathol. 20:158-164.

Gooding, M. J., Dimmock, J. P. R. E., France, J., and Jones, S. A. 2000. Green leaf area decline of wheat flag leaves: the influence of fungicides and relationships with mean grain weight and grain yield. Ann. Appl. Biol. 136:77-84.

Horsfall, J. G., and Barratt, R. W. 1945. An improved grading system for measuring plant diseases. (Abstr.) Phytopathology 35:65.

Jørgensen, L. N., Nielsen, G. C., Orum, J. E., Jensen, J. E., and Pinnschmidt, H. O. 2008. Integrating disease control in winter wheat-Optimizing fungicide input. Outlooks Pest Manage. 19:206-213.

King, J. E., Cook, R. J., and Melville, S. C. 1983. A review of Septoria diseases of wheat and barley. Ann. Appl. Biol. 103:345-373.

Krupinsky, J. M., Tanaka, D. L., Lares, M. T., and Merrill, S. D. 2004. Leaf spot diseases of barley and spring wheat as influenced by preceding crops. Agron. J. 96:259-266.

Kutcher, H. R., Johnston, A. M., Bailey, K. L., and Malhi, S. S. 2011. Managing crop losses from plant diseases with foliar fungicides, rotation and tillage on a Black Chernozem in Saskatchewan, Canada. Field Crops Res. 124:205-212.

Lancashire, P. D., Bleiholder, H., Langelüddecke, P., Stauss, R., van den Boom, T., Weber, E., and Witzenberger, A. 1991. A uniform decimal code for growth stages of crops and weeds. Ann. Appl. Biol. 119:561-601.

Littell, R. C., Milliken, G. A., Stroup, W. W., and Wolfinger, R. D. 1996. SAS System for Mixed Models. SAS Institute, Cary, NC.

Lopez, J. A., Rojas, K., and Swart, J. 2015. Economics of foliar fungicide applications in winter wheat in Northeast Texas. Crop Prot. 67:35-42.

Loyce, C., Meynard, J. M., Bouchard, C., Rolland, B., Lonnet, P., Bataillon, P., Bernicot, M. H., Bonnefoy, M., Charrier, X., Debote, B., Demarquet, T., Duperrier, B., Félix, I., Heddadj, D., Leblanc, O., Leleu, M., Mangin, P., Méausoone, M., and Doussinault, G. 2008. Interaction between cultivar and crop management effects on winter wheat diseases, lodging, and yield. Crop Prot. 27:1131-1142.

McFadden, W. 1991. Etiology and epidemiology of leaf spotting diseases in winter wheat in Saskatchewan. Ph.D. thesis, University of Saskatchewan, Saskatoon, SK, Canada.

Ransom, J. K., and McMullen, M. V. 2008. Yield and disease control on hard winter wheat cultivars with foliar fungicides. Agron. J. 100:1130-1137.

Shah, D. A., and Madden, L. V. 2004. Nonparametric analysis of ordinal data in designed factorial experiments. Phytopathology 94:33-43.

Stover, R. W., Francl, L. J., and Jordahl, J. G. 1996. Tillage and fungicide management of foliar diseases in a spring wheat monoculture. J. Prod. Agric. 9:261-265.

Thompson, N. M., Epplin, F. M., Edwards, J. T., and Hunger, R. M. 2014. Economics of foliar fungicides for hard red winter wheat in the USA southern Great Plains. Crop Prot. 59:1-6.

Turkington, T. K., Beres, B. L., Kutcher, H. R., Irvine, B., Johnson, E. N., O’Donovan, J. T., Harker, K. N., Holzapfel, C. B., Mohr, R., Peng, G., and Stevenson, F. C. 2016. Winter wheat yields are increased by seed treatment and fall-applied fungicide. Agron. J. 108:1379-1389.

Walpole, P. R., and Morgan, D. G. 1974. The influence of leaf removal upon the development of the grain of winter wheat. Ann. Bot. 38:779-782.

Wang, H., Fernandez, M. R., Clarke, F. R., DePauw, R. M., and Clarke, J. M. 2002. Effect of leaf spotting diseases on grain yield and seed traits of wheat in southern Saskatchewan. Can. J. Plant Sci. 82:507-512.

Wegulo, S. N., Zwingman, M. V., Breathnach, J. A., and Baenziger, S. 2011. Economic returns from fungicide application to control foliar fungal diseases in winter wheat. Crop Prot. 30:685-692.

Wiik, L. 2008. Yield and disease control in winter wheat in southern Sweden during 1977-2005. Crop Prot. 28:82-89.

Williams, P. D., Sobering, J., and Antoniszyn, J. 1998. Protein testing methods. Pages 37-47 in: Wheat Protein Production and Marketing. D. B. Fowler, ed. University of Saskatchewan Extension Press, Saskatoon, SK, Canada.

Willyerd, K. T., Bradley, C. A., Chapara, V., Conley, S. P., Esker, P. D., Madden, L. V., Wise, K. A., and Paul, P. A. 2015. Revisiting fungicide-based management guidelines for leaf blotch diseases in soft red winter wheat Plant Dis. 99:1434-1444. 